\title{
Originals
}

\section{Non-Enzymatically Glycosylated Serum Protein in Diabetes Mellitus: An Index of Short-Term Glycaemia}

\author{
L. Kennedy ${ }^{1}$, T. D. Mehl, W. J. Riley, and T. J. Merimee \\ Department of Medicine, Endocrinology Division, University of Florida, Gainesville, Florida, USA
}

\begin{abstract}
Summary. We measured non-enzymatically-glycosylated serum protein by a colorimetric assay in 107 diabetic and 82 control subjects. The mean level in diabetics was more than twice that in controls. Cross sectional and longitudinal studies in diabetic patients showed that glycosylated serum protein levels correlated with both fasting serum glucose and glycosylated haemoglobin levels. The correlation between glycosylated serum protein and fasting serum glucose was closer in Type 2 than in Type 1 diabetes. Treatment aimed at improving control in eight poorly controlled diabetic patients resulted in a $37 \%$ mean fall in glycosylated serum protein within one week, whereas glycosylated haemoglobin decreased only $8 \%$. These studies confirm that non-enzymatic glycosylation of serum proteins is enhanced in diabetes. Measurement of glycosylated serum protein appears to provide an index of glycaemia over the preceding several days. It has the advantage of detecting improvements in glycaemic control much sooner than does glycosylated haemoglobin measurement.
\end{abstract}

Key words: Glycosylation, serum, protein, haemoglobin, glycaemia.

Several classes of proteins may undergo post-synthetic modification by the non-enzymatic addition of glucose or a glucose derived product. Haemoglobin was the first protein shown to be thus modified [1]. Subsequent studies have demonstrated a similar effect of glucose on lens crystallins [2], collagen [3], erythrocyte membrane proteins [4], albumin and other serum proteins $[5,6]$.

Glycosylated haemoglobin, once formed, is stable and accumulates throughout the red cell's life span.

${ }^{1}$ Present address: Sir George E. Clark Metabolic Unit, Royal Victoria Hospital, Belfast BT12 6BA, UK
Since its formation in vivo is related to the amount of free glucose available, it has been suggested that, in the diabetic state, glycosylated haemoglobin levels will reflect integrated glucose concentrations over the previous several weeks [7].

In this report, we examine the relationship of glycosylated serum protein to other indices of control in cross-sectional and prospective studies in diabetic patients. The results support the hypothesis that glycosylated serum protein levels accurately reflect the degree of glycaemia during a period of several days to two weeks before its measurement. We would suggest that measurement of glycosylated serum protein has considerable clinical potential in the management and investigation of diabetes. In particular it may be useful in detecting changes in glycaemia in response to treatment earlier than is possible with glycosylated haemoglobin.

\section{Patients and Methods}

\section{Patients}

Seventy patients referred to diabetic clinics of the Shands Teaching Hospital and Veterans Administration Hospital, Gainesville, Florida, and 37 subjects attending a summer diabetes camp were studied. Of these 107 diabetic subjects, 66 were classified as having Type 1 (insulin dependent) and 41 Type 2 (insulin independent) diabetes mellitus [8]. Their ages ranged from 7 to 11 years and the duration of diabetes from 3 months to 36 years. All Type 1 and 31 Type 2 patients were receiving insulin therapy. Of the ten remaining Type 2 patients, six were treated by diet and four by diet and sulphonylurea drugs.

Eighty-two age and sex-matched non-diabetic control subjects (fasting serum glucose $<6.1 \mathrm{mmol} / \mathrm{l}$ ) were also studied.

\section{Methods}

Every subject was studied on at least one occasion. Eight diabetic patients who were considered to be in poor control were studied over the course of one week during which their control was 


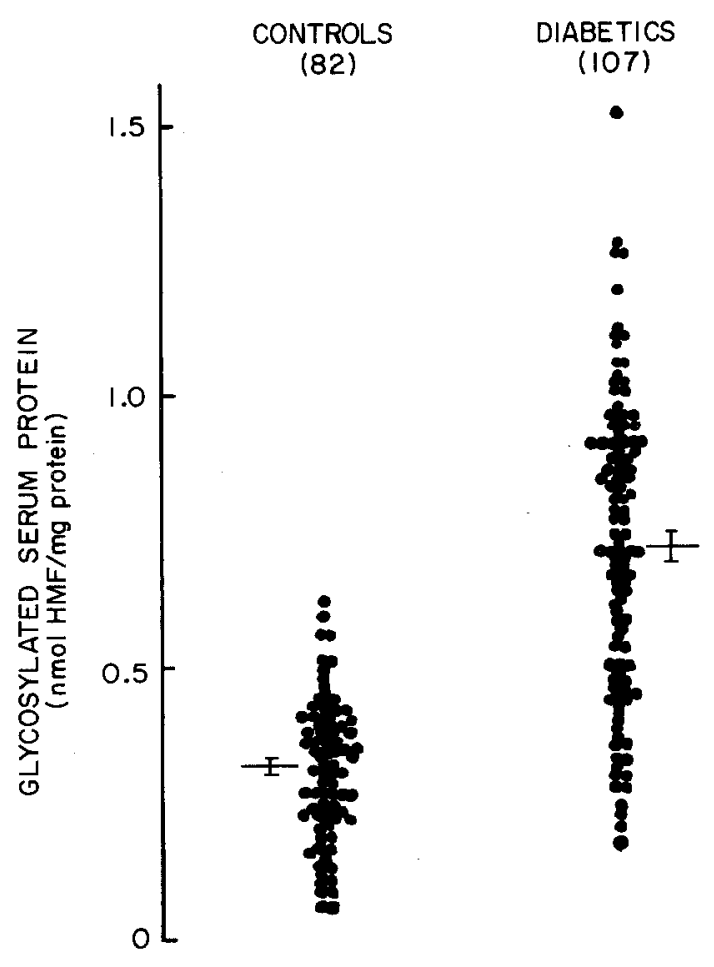

Fig. 1. Glycosylated serum protein levels in 82 control and 107 diabetic subjects. Mean \pm SEM are indicated by the bars

improved. This was achieved in five patients by pulsed subcutaneous administration of insulin via a portable infusion pump (autosyringe) while they were hospitalized in the Clinical Research Centre. In the other three, improved control was achieved by manipulation of insulin dosage on an outpatient basis, and monitored by frequent home urine sugar testing and fasting serum glucose measurements on alternate days.

Venous blood samples were obtained after an overnight fast and, in the case of the diabetic patients, before their morning insulin injection or sulphonylurea drug. Serum was separated immediately and serum glucose was measured by a standard glucose oxidase method. Serum was stored at $-20^{\circ} \mathrm{C}$ until glycosylated serum protein assay. Haemolysates were prepared immediately for glycosylated haemoglobin assay.

Glycosylated serum protein was measured by the colorimetric method outlined by McFarland et al. [5], with the modification that serum was first dialyzed against normal saline to prevent spurious elevation of glycosylated serum protein levels due to free glucose [9]. In this procedure, $120 \mu \mathrm{l}$ serum is diluted to $540 \mu \mathrm{l}$ with distilled water; an equal volume of oxalic acid $(1 \mathrm{~mol} / \mathrm{l})$ is added and after incubation at $100{ }^{\circ} \mathrm{C}$ for $5 \mathrm{~h}$ 'adducted' glucose is hydrolysed as 5-hydroxymethylfurfural (HMF). Protein is precipitated by the addition of $240 \mu \mathrm{l}$ trichloroacetic acid $(600 \mathrm{~g} / 1) ; 300 \mu \mathrm{l}$ thiobarbituric acid $(50 \mathrm{mmol} / \mathrm{l})$ is then added to $900 \mu \mathrm{l}$ of the supernatant and incubated at $37^{\circ} \mathrm{C}$ for $15 \mathrm{~min}$. After a further 20 min at room temperature, the absorbence at $443 \mathrm{~nm}$ is measured. For each sample a blank was run in which the serum was incubated at room temperature for $41 / 2 \mathrm{~h}$ with $300 \mu \mathrm{l}$ freshly prepared $\mathrm{NaHB}_{4}$ $(100 \mathrm{mmol} / \mathrm{l})$ in $\mathrm{NaOH}(10 \mathrm{mmol} / 1) ; 120 \mu \mathrm{l}$ acetone (reagent grade) was then added before incubation with oxalic acid and precipitation with trichloroacetic acid. The 'adducted' glucose is reduced to a non-reactive form by $\mathrm{NaBH}_{4}$ [1]. Glycosylated serum protein is calculated as nmol $\mathrm{HMF} / \mathrm{mg}$ protein using pure $5-\mathrm{HMF}$ (Sigma Chemical Company) as standard. When samples and blanks are assayed in duplicate, the coefficient of variation for the complete procedure is $8 \%$ within, and $12 \%$ between assays. In the longitudinal studies all the samples of each individual patient were processed in one single assay run to eliminate interassay variation. Glycosylated serum protein levels did not change significantly in samples stored at $-20^{\circ} \mathrm{C}$ for up to 4 months. Protein in dialyzed serum samples was measured by the biuret method.

Glycosylated haemoglobin was measured by one of two methods. In patients attending hospital clinics, the column chromatography method of Welch and Boucher was used [10]. These determinations were carried out in a temperature controlled room within $72 \mathrm{~h}$ of blood sampling, the haemolysates having been stored in the interim at $-20^{\circ} \mathrm{C}$. Glycosylated haemoglobin is expressed as percentage $\mathrm{HbA}_{1}$ with an upper limit of normal, in our hands, of $8.8 \%$. For patients attending the diabetic summer camp, a colorimetric method was used, in which glycosylated haemoglobin is expressed as absorbence at $443 \mathrm{~nm} / 10 \mathrm{mg}$ haemoglobin [11]. Haemolysates in this case were stored and transported at $4{ }^{\circ} \mathrm{C}$ before assay. All the above determinations were run in duplicate.

\section{Statistics}

Between-patient comparisons were analyzed by Student's t-test for unpaired data, and within-patient comparisons by Student's $\mathrm{t}$-test for paired data. Correlations were performed by linear regression analysis.

\section{Results}

Figure 1 shows glycosylated serum protein levels in diabetic and control subjects. The mean \pm SEM in diabetics was $0.72 \pm 0.03 \mathrm{nmol} \mathrm{HMF} / \mathrm{mg}$ protein compared with $0.32 \pm 0.01$ in controls $(\mathrm{p}<0.0001)$. The ranges of values in Type 1 and Type 2 diabetic patients were similar, but the mean value of $0.79 \pm$ $0.03 \mathrm{nmol} \mathrm{HMF} / \mathrm{mg}$ protein in Type 1 patients was significantly higher than that of $0.60 \pm 0.04$ in Type 2 patients $(\mathrm{p}<0.001)$.

In diabetic patients, glycosylated serum protein levels were not related to sex, age, duration of diabetes or the presence or absence of retinopathy. In control subjects there was a trend towards increasing glycosylated serum protein levels with advancing age, but this was not statistically significant.

Glycosylated serum protein levels in the 107 diabetic patients showed a significant positive correlation with fasting serum glucose (Fig. 2). This correlation was closer in the 41 patients with Type 2 diabetes $(r=0.70, p<0.001)$ than in the 66 patients with Type 1 diabetes $(\mathrm{r}=0.34, \mathrm{p}<0.01)$.

A positive correlation was also found between glycosylated serum protein and glycosylated haemoglobin levels in the diabetic patients. Figure 3 shows this correlation for the 37 diabetic camp patients in whom glycosylated haemoglobin was measured by the colorimetric method. Here the correlation between glycosylated serum protein and fasting serum 


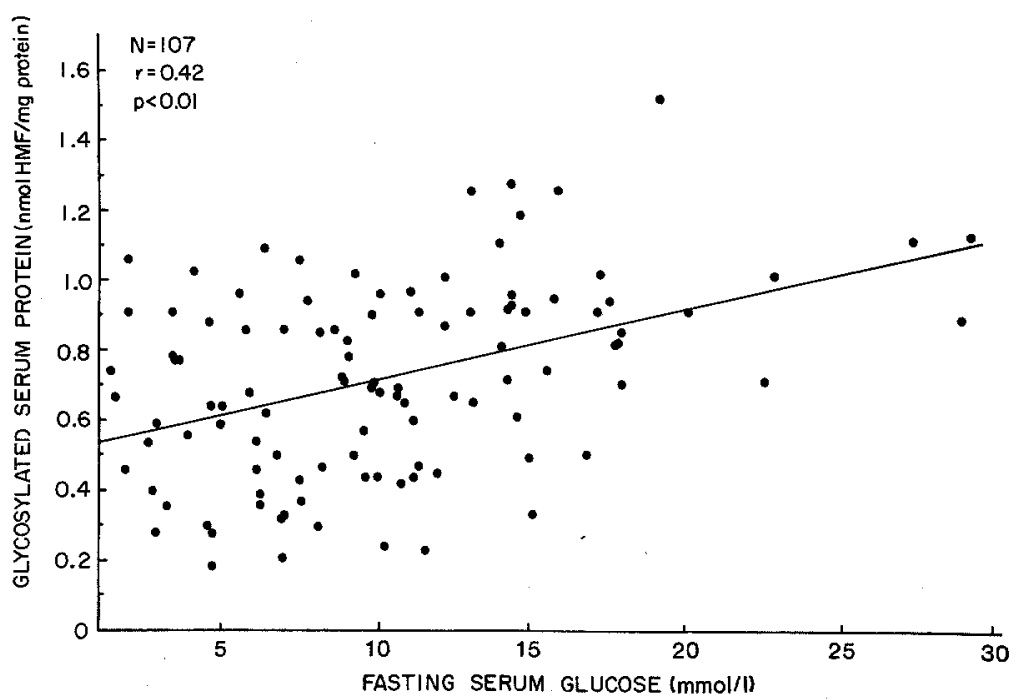

Fig. 2. Relation between glycosylated serum protein and fasting serum glucose in 107 diabetic subjects

glucose was not as close $(\mathrm{r}=0.36, \mathrm{p}<0.05)$. A similar correlation between glycosylated serum protein and glycosylated haemoglobin $(\mathrm{r}=0.50$, $\mathrm{p}<0.01$ ) was seen in 45 clinic patients in whom $\mathrm{HbA}_{1}$ was measured by column chromatography.

Figure 4 demonstrates the effect on $\mathrm{HbA}_{1}$, fasting serum glucose and glycosylated serum protein of improving diabetic control over one week. All eight patients noted a decrease in glycosuria measured semiquantitatively in pre-meal urine samples (Clinitest), and $24 \mathrm{~h}$ urinary glucose excretion decreased in all five patients treated with the autosyringe. During this period a much greater percentage reduction was seen in glycosylated serum protein levels than in $\mathrm{HbA}_{1}$. The latter remained considerably elevated in all patients, whereas glycosylated serum protein levels decreased to within the normal range in four patients.

\section{Discussion}

One of the major problems in both the clinical management of diabetes and the investigation of its complications has been the lack of a reliable objective index of glycaemic control. The increased availability of accurate methods for measurement of glycosylated haemoglobin in the last five years has represented an important advance in this regard [10-13]. However, this measurement is limited by the fact that clinically significant reductions in glycosylated haemoglobin may not be apparent for at least four weeks after the attainment of improved control [14]. Furthermore, recent data indicate that the rate of formation of glycosylated haemoglobin in vivo is considerably faster than its rate of disappearance, and that levels are

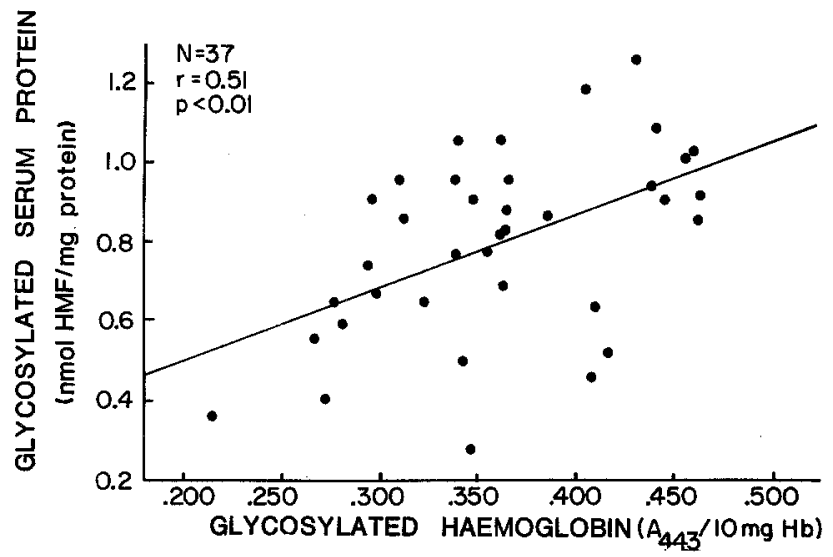

Fig. 3. Relation between glycosylated serum protein and glycosylated haemoglobin in 37 patients with Type 1 diabetes

likely to be disproportionately representative of high rather than average glucose concentrations [15]. A measurement which would reflect integrated blood glucose over a shorter period of time would have the obvious advantage of enabling quicker assessment of the efficacy of any change in therapy.

Studies in vitro have shown that all classes of serum proteins may be non-enzymatically glycosylated. The extent of this glycosylation depends on the glucose concentration to which the proteins are exposed, the length of time of exposure and the temperature of incubation [16]. Such glycosylation appears to be a stable modification, since ${ }^{125} \mathrm{I}$-albumin isolated from rat serum up to three days after injection of glycosylated ${ }^{125} \mathrm{I}$-albumin was recovered only in glycosylated form [17]. This suggests that assay of glycosylated serum protein in human diabetic subjects should provide a measurement of integrated glycaemia, analogous to glycosylated haemo- 


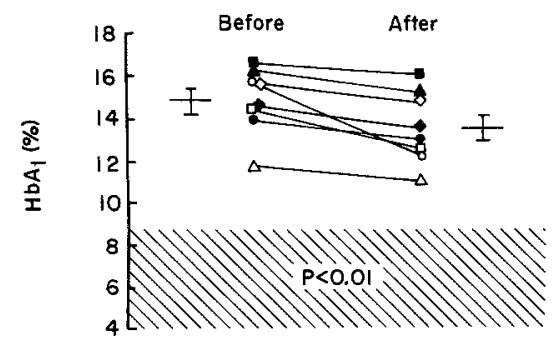

Percent mean
reduction

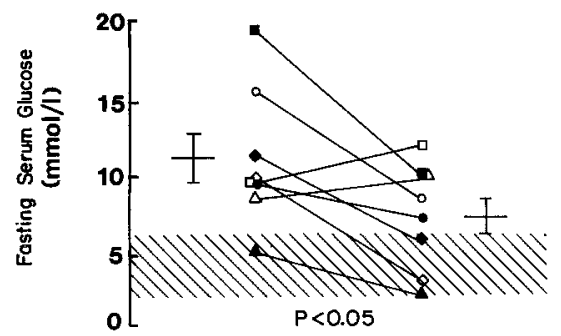

8.4
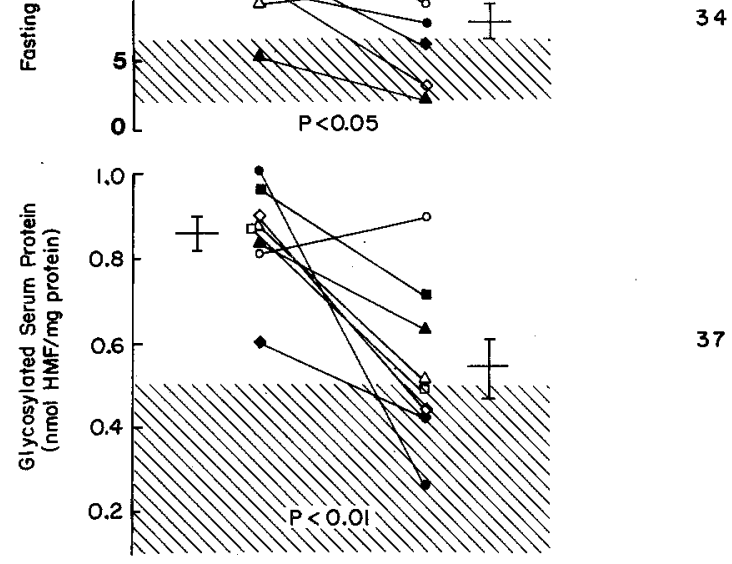

Fig. 4. Levels of glycosylated haemoglobin, fasting serum glucose and glycosylated serum protein in eight diabetic patients before and after control was improved over the course of one week. Shaded areas represent normal ranges. Mean \pm SEM levels are indicated by the bars

globin, but for a much shorter period due to the shorter half-life of serum proteins. The results of the present study strongly support this hypothesis.

First, glycosylated serum protein levels were two to three times higher in diabetic than non-diabetic subjects, as is the case with glycosylated haemoglobin in most reports [7]. The values in diabetic patients ( 0.18 to $1.52 \mathrm{nmol} \mathrm{HMF} / \mathrm{mg}$ protein) were approximately a quarter of those found for glycosylated haemoglobin by Pecoraro et al. [18] (1.3 to $5.5 \mathrm{nmol}$ $\mathrm{HMF} / \mathrm{mg}$ haemoglobin), using a similar colorimetric method and 5-HMF as standard. This would be expected since the half-life of haemoglobin (and hence exposure to glucose) is approximately four to five times that of serum proteins. The higher mean glycosylated serum " protein level in Type 1 patients compared with Type 2 is, we feel, a reflection of the sample population. Whereas glycosylated haemoglobin levels were within the normal range in $20 \%$ of Type 2 patients, this was the case in only $5 \%$ of Type 1 patients, suggesting that overall the Type 1 group was more severely hyperglycaemic.
Second, glycosylated serum protein levels correlated only with other parameters of glycaemic control and not with such aspects as age, sex, duration of diabetes, or presence or absence of retinopathy, none of which would be expected to influence the degree of glycaemia. The closer correlation with fasting serum glucose in Type 2 patients argues strongly that glycosylated serum protein is a measure of shortterm glycaemia, for it has recently been shown that in Type 2 diabetes blood glucose concentrations remain fairly stable, with close correlation between fasting and $24 \mathrm{~h}$ integrated values $[19,20]$. In Type 1 diabetes, on the other hand, considerable perturbations of glucose levels may occur in minutes to hours, so the level at any one point in time may be misleading as to the integrated level of glycaemia. Therefore a poorer correlation between fasting serum glucose and any measurement of integrated glucose levels in Type 1 diabetes compared with Type 2 could be predicted. By the same token one might predict that glycosylated serum protein, if it does reflect glycaemia for a period of several days to two weeks, would correlate more closely with glycosylated haemoglobin levels than with fasting serum glucose levels in Type 1 diabetes. Yue et al. similarly found a high degree of correlation between glycosylated haemoglobin and glycosylated serum protein in 45 diabetic patients [21].

Finally our short term prospective study shows that within one week of improved glycaemic control glycosylated serum protein levels fell much more than glycosylated haemoglobin levels (Fig. 4). A statistically significant reduction in glycosylated haemoglobin levels was observed, but the magnitude of the change in most individuals was small enough that most clinicians would hesitate to interpret it as being truly clinically significant. The reduction in glycosylated serum protein levels was not only statistically significant, but, in terms of basal levels, was more than four times greater than the reduction in glycosylated haemoglobin. In four cases glycosylated serum protein levels fell to within the normal range whereas in every case glycosylated haemoglobin remained considerably elevated. These observations are consistent with the finding of Dolhofer and Wieland in one insulin treated diabetic patient that glycosylated haemoglobin was lowered by $15 \%$ after 20 days whereas glycosylated albumin had dropped by more than $50 \%$ [22].

We believe that measurement of glycosylated serum protein will prove a useful tool, enabling the clinician to make more rapid assessment of therapeutic manoeuvres aimed at improving glycaemia than is possible with glycosylated haemoglobin. Serial determinations of glycosylated serum protein 
should also be useful in prospective studies to evaluate the relation of glycaemic control to the development of diabetic complications.

There has been considerable interest in the possibility that non-enzymatic glycosylation of proteins may alter their function and may actually contribute to the development of long term complications in diabetes [7, 23]. In an intriguing preliminary communication McVerry et al claimed that repeated injections of non-enzymatically glycosylated plasma proteins into non-diabetic mice led to the development of glomerular basement membrane thickening on electron microscopic examination, a feature characteristic of diabetic renal disease [24]. Accurate measurement of non-enzymatic glycosylation of serum proteins has an obvious role in the investigation of such a potentially important pathogenetic process in human diabetes.

Acknowledgements. We are indebted to Betty Russell for her skilled technical assistance; to Dr. Arlan Rosenbloom, other members of the Paediatric Endocrine Division, and the staff of the Clinical Research Centre, University of Florida for their assistance in obtaining samples; to Dr. Kenneth $\mathrm{H}$. Gabbay and his laboratory staff, Children's Hospital Medical Centre, Boston, Maryland for performing glycosylated haemoglobin measurements on samples from the diabetic summer camp; and to Toni Toal for preparing the manuscript. This work was supported in part by grants (AM00561 and AM-18130) from the National Institute of Arthritis and Metabolism and Digestive Diseases, The National Institutes of Health, and by The Florida Citrus Commission.

\section{References}

1. Holmquist WR, Schroeder WA (1966) A new N-terminal blocking group involving a Schiff base in hemoglobin $A_{1 c}$. Biochemistry 5: 2489-2503

2. Stevens VS, Rouzer CA, Monnier VM, Cerami A (1978) Diabetic cataract formation: potential role of glycosylation of lens crystallins. Proc Natl Acad Sci USA 75: 2918-2922

3. Robins SP, Bailey AJ (1972) Age related changes in collagen: the identification of reducible lysine - carbohydrate condensation products. Biochem Biophys Res Commun 48: 76-84

4. Bailey AJ, Robins SP, Tanner MJA (1976) Reducible components in the proteins of human erythrocyte membrane. Biochim Biophys Acta 434: 51-57

5. McFarland KK, Catalano EW, Day JF, Thorpe SR, Baynes JW (1979) Nonenzymatic glucosylation of serum proteins in diabetes mellitus. Diabetes 28: 1011-1014

6. Dolhofer R, Wieland OH (1979) Glycosylation of serum albumin: elevated glycosyl-albumin in diabetic patients. FEBS Lett 103: $282-286$

7. Bunn HF, Gabbay KH, Gallop PM (1978) The glycosylation of hemoglobin: relevance to diabetes mellitus. Science 200: $21-27$
8. National Diabetes Data Group (1979) Classification and diagnosis of diabetes mellitus and other categories of glucose intolerance. Diabetes 28: 1039-1057

9. Kennedy AL, Mehl TD, Merimee TJ (1979) Nonenzymatically glycosylated serum protein: spurious elevation due to free glucose in serum. Diabetes 29: 413-415

10. Welch SG, Boucher BJ (1978) A rapid microscale method for the measurement of haemoglobin $A_{1(a+b+c)}$. Diabetologia 14: 209-211

11. Gabbay KH, Sosenko JM, Banuchi GA, Mininsohn MJ, Fluckinger R (1979) Glycosylated hemoglobins: increased glycosylation of hemoglobin $\mathrm{A}$ in diabetic patients. Diabetes 28: $337-340$

12. Fluckiger R, Winterhalter KH (1976) In vitro synthesis of $\mathrm{HbA}_{1 \mathrm{c}}$. FEBS Lett 71: 356-360

13. Cole RA, Soeldner JS, Dunn PJ, Bunn HF (1978) A rapid method for the determination of glycosylated hemoglobins using high pressure liquid chromatography. Metabolism 27: 289-301

14. Koenig RJ, Peterson CM, Jones RL, Saudek C, Lehrman M, Cerami A (1976) Correlation of glucose regulation and hemoglobin $A_{1 c}$ in diabetes mellitus. N Engl J Med 295: 417-420

15. Boden G, Master RW, Gordon SS, Shuman CR, Owen OE (1980) Monitoring metabolic control in diabetic out patients with glycosylated hemoglobin. Ann Intern Med 92: 357-360

16. Day JF, Thorpe SR, Baynes JW (1979) Nonenzymatically glucosylated albumin. J Biol Chem 254: 595-597

17. Day JF, Thornburn RW, Thorpe SR, Baynes JW (1979) Nonenzymatic glucosylation of rat albumin. J Biol Chem 254: 934-940

18. Pecoraro RE, Graf RJ, Halter JB, Beiter H, Porte DJr (1979) Comparison of a colorimetric assay for glycosylated hemoglobin with ion-exchange chromatography. Diabetes 28 : 1120-1125

19. Holman RR, Turner RC (1977) The quest for basal normoglycaemia. Lancet I: $469-474$

20. Paisey RB, Bradshaw P, Hartog M (1980) Home blood glucose concentrations in maturity onset diabetes. Br Med $\mathrm{J} \mathrm{I}$ : 596-598

21. Yue DK, Morris K, McLennon S, Turtle JR (1980) Glycosylation of plasma protein and its relation to glycosylated hemoglobin in diabetes. Diabetes 29: 296-300

22. Dolhofer R, Wieland OH (1980) Increased glycosylation of serum albumin in diabetes mellitus. Diabetes 29: 417-422

23. Peterson CM, Jones RL (1977) Minor hemoglobins, diabetic "control", and diseases of post-synthetic protein modification. Ann Intern Med 87: 489-491

24. McVerry BA, Hopp A, Fisher C, Huehns ER (1980) Production of pseudodiabetic renal glomerular changes in mice after repeated injections of glucosylated proteins. Lancet I: $738-740$

Received: 17 November 1980 , and in revised form: 9 February 1981

Dr. L. Kennedy

Sir George E. Clark Metabolic Unit

Royal Victoria Hospital

Grosvenor Road

Belfast BT12 6BA, UK 